\title{
Kepemimpinan Efektif di Pesantren
}

\author{
Ulfah Amalia $^{1 *}$, Dindin Solahudin $^{2}, \&$ Yuliani $^{3}$ \\ 132jurusan Manajemen Dakwah, Fakultas Dakwah dan Komunikasi, UIN Sunan Gunung Djati \\ Bandung \\ 2jurusan Pengembangan Masyarakat Islam, Fakultas Dakwah dan Komunikasi, UIN Sunan \\ Gunung Djati Bandung \\ *Email:ulfahamalia33@,Gmail.Com
}

\begin{abstract}
ABSTRAK
Tujuan penelitian ini adalah untuk mengetahui strategi yang telah dirumuskan K.H. Agus Yudhi Mubaarak dalam pengelolaan pesantren, program K.H. Agus Yudhi Mubaarak dalam pengelolaan pesantren, dan implementasi program K.H. Agus Yudhi Mubaarak dalam pengelolaan pesantren. Penelitian ini menggunakan metode deskriptif dengan pendekatan kualitatif. Hasil penelitian yang ditemukan menunjukan bahwa kemajuan pondok pesantren Sabiilunnaja tidak terlepas dari strategi yang telah dirumuskan K.H. Agus Yudhi Mubaarak yaitu dengan pengenalan sifat Rububiyah, juga mengenalkan pembiasaan mensinergikan antara hubungan horizontal dan vertikal serta meningkatkan intelektualisme dan spiritualisme. Kemudian strategi tersebut dipolakan kepada program-program kegiatan santri. Diantaranya ada program jangka pendek, menengah, dan jangka panjang. Implementasi dari program tersebut berjalan dengan lancar yang tentunya melibatkan seluruh santri dan dewan guru. Dengan demikian, maka seluruh kegiatan santri menjadi dasar berkembangnya Pondok Pesantren Sabiilunnaja yang dikelola oleh K.H. Agus Yudhi Mubaarak dalam pengelolaan pondok pesantren.
\end{abstract}

Kata kunci: Strategi; Pengelolaan; Pesantren.

\section{ABSTRACT}

The purpose of this research is to find out the strategies that have been formulated by $K . H$. Agus Yudhi Mubaarak in the management of Islamic boarding schools, K. H. Agus Yudhi Mubaarak's program in the management of Islamic boarding schools, and the implementation of the K. H. Agus Yudhi Mubaarak program in the management of Islamic boarding schools. This study uses a descriptive method with a qualitative approach. The results of the study found that the progress of the Sabiilunnaja Islamic boarding school was inseparable from the strategy formulated by K. H. Agus Yudhi Mubaarak, namely by introducing the nature of Rububiyah, 
also introducing the habit of synergizing between horizontal and vertical relations and increasing intellectualism and spiritualism. Then the strategy is modeled on the activities of the santri programs. Among them are short, medium and long term programs. The implementation of the program went smoothly, which of course involved all students and the board of teachers. Thus, all santri activities are the basis for the development of the Sabiilunnaja Islamic Boarding School which is managed by K. H. Agus Yudhi Mubaarak in the management of Islamic boarding schools.

Keywords: Strategy; Management; Boarding school.

\section{PENDAHULUAN}

Salah satu lembaga Islam tertua di Indonesia adalah pondok pesantren. Berdirinya oleh ulama sejak dulu, yang sampai sekarang keberadaannya terus berkembang. Adanya pondok pesantren menjadi salah satu bagian dari sistem kehidupan umat islam sekaligus penyangga budaya masyarakat islam dan bangsa indonesia (Galba; 1995: 1).

Mastuhu mengungkapkan pondok pesantren yaitu satu lembaga pendidikan tradisional Islam yang memahami, mempelajari, menghayati dan mengamalkan ajaran Islam dengan mendasari pentingnya moral keagamaan sebagai pedoman akhakul karimah dalam kehidupan sehari-hari dalam ajaran kiai dan menjadikan kitab kuning sebagai sumber primernya.

Pesantren atau sering dikenal dengan istilah pondok pesantren bisa dimaknai sebagai wadah untuk para pecinta ilmu yang ingin belajar atau mengaji ilmu pengetahuan agama kepada kiai, yang mayoritasnya sering dikatakan kobong atau asrama, yang di dalamnya terdapat beberapa santri.

Dari data Pondok pesantren Kabupaten Bandung Barat ada sebanyak 475 Pondok Pesantren baik yang berada di pertengahan kota maupun di desa. Pondok pesantren yang berada di kampung-kampung atau desa yang berada di Kabupaten Bandung Barat memudahkan para orangtua yang benar-benar menginginkan anaknya mendalami ilmu agama dan berprilaku baik sesuai yang dinajurkan dalam Al-Qur'an dan sunahnya tanpa mengeluarkan banyak biaya. Namun, yang maju dan berkembang itu tidaklah banyak. Oleh sebab itu, sangatlah penting peran seorang kiai atau pimpinan dalam mengelola pondok pesantren.

Sebuah organisasi atau lembaga sangat membutuhkan sosok seorang pemimpin, terlebih perannya dalam pengelolaan. Peran kepemimpinan juga menjadi tolak ukur terciptanya suatu organisasi atau lembaga yang menjadikan dambaan bagi masyarakat setempat khususnya umumnya bagi khalayak.

Dalam setiap organisasi atau lembaga kepemimpinan memiliki arti strategis, termasuk lembaga keagamaan yang bergerak dalam bidang pendidikan, salah satunya adalah pondok pesantren. Pimpiman dapat menentukan berhasil atau tidaknya yang dipimpinnya. Oleh sebab itu, seorang pemimpin harus tangguh, cerdas, serta sabar supaya bisa mengendalikan bawahannya. 
Kepemimpinan seorang kiai di sebuah pondok pesantren sangatlah berperan penting terkhusus dalam bidang pengelolaannya. Seorang kiai menguasai dan mengendalikan seluruh sektor kehidupan pesantren. Kedudukan kiai merupakan kedudukan ganda, sebagai seorang pengasuh sekaligus seorang pemilik pesantren.

Pondok Pesantren Sabiilunnaja telah berdiri sejak tahun 1998 diatas tanah dari bapak (Jend) Jaja Djauhari dengan tipologi salafiyah murni yang dipimpin oleh Drs. K. H. Agus Yudhi Mubaarak, S. Ag., M. M. Pd. yang bermula dengan pembentukan pengajian rutinan malam rabu dengan peserta pengajian kurang dari 10 orang. Kemudian pimpinan berpikir kalau seperti ini tidak akan maju-maju. Maka dari itu pimpinan beserta tokoh masyarakat dan agama merencanakan untuk membangun sebuah pondok pesantren. Maka terbangunlah sebuah pondok pesantren pada tahun itu juga, tahun 1998 dengan menerima santri putri saja, kemudian pada tahun 2000 barulah pondok Pesantren Sabilunnaja menerima santri putra. Berdirinya Pondok Pesantren Sabilunnaja didasari dengan cita-cita ingin dapat berperan serta untuk membina umat dalam melaksanakan tugasnya sebagai khalifah di muka bumi.

Maju serta berkembangnya suatu organisasi dikendalikan oleh seorang pemimpin yang dengan handalnya mampu mengendalikan dan menggerakan pasepase kelembagaan yang berada diwilayahnya sampai tercapainya tujuan yang telah dirumuskan secara maksimal. Sama halnya dengan Pesantren Sabiilunnaja, bisa maju seperti ini disebabkan adanya seorang pemimpin yang senantiasa menjalankan program yang diterapkan serta strategi yang dirumuskan seorang pemimpin dari tahun ke tahunnya.

Adapun penelitian sebelumnya, dari skripsi Eka Verayanti pada tahun 2004 yang berjudul Peranan Pemimpin Kopontren Al-Manar dalam Meningkatkan Motivasi Kerja Pengurus (Penelitian di Pondok Pesantren Al-Manar Jl. Purnawarman Barat No. 71 Purwakarta), bahsawannya dari data hasil penelitian saudara Eka Verayanti dapat disimpulkan bahwa yang ada dapat disimpulkan bahwa peranan pemimpin kopontren Al-Manar dalam meningkatkan motivasi kerja pengurus di kategorikan baik usaha-usaha yang dikembangkan pemimpin dengan membangun komitmen yang tinggi untuk memajukan kopontren menetapkan mekanisme kerja dan bersifat objektif terhadap pujian dan kritikannya dapat mendorong para bawahannya bekerja dengan baik. Serta kegiatan yang dikembangkan pemimpin kopontren Al-Manar pada dasarnya membebrikan pengarahan dan wewenang penuh kepada para bawahan-Nya agar diantara keduanya ada saling keterbukaan dan kerjasama yang baik pula. Adapun perbedaannya, terdapat pada pengelolaan. Penelitian terdahulu meneliti peran pemimpin dalam meningkatkan motivasi kerja pengurus sedangkan peneliti adalah peran kepemimpinan dalam pengelolaan pesantren. 
Lokasi pesantren yang strategis berada di tengah-tengah kota berdampingan dengan Kantor KUA dan Masjid Besar Cipeundeuy, serta di sekitarnya bertetangga dengan Kantor UPT Pendidikan Cipeundeuy, KORAMIL Cipeundeuy, Kantor Kecamatan Cipeundeuy, Kantor POLSEK Cipeundeuy, serta sangat dekat dari Pasar tradisional Cipeundeuy dan terminal Cipeundeuy membuat lokasi mudah dikunjungi dari arah manapun.

Kemudian peneliti merasa penasaran dan memberi beberapa pertanyaan, yang dipolakan menjadi rumusan masalah, yaitu: (1) bagaimana strategi yang dilakukan K. H. Agus yudhi Mubaarak dalam pengelolaan pesantren? (2) apa program yang dilakukan K. H. Agus Yudhi Mubaarak dalam pengelolaan pesantren, dan (3) bagaimana implementasi program pimpinan dalam pengelolaan pesantren.

Penelitian ini menggunakan metode deskriptif. Pemilihan metode penelitian ini didasarkan pada tujuan untuk menjelaskan gambaran secara luas perihal bagaimana peran kepemimpinan K. H. Agus Yudhi Mubaarak dalam pengelolaan Pesantren Persatuan Sabiilunnaja Cipeundeuy Bandung Barat melalui proses bagaimana strategi yang dirumuskan oleh pimpinan dan menggali secara mendalam program-program yang telah pimpinan rancang serta pengimplementasian dalam program-program yang telah di rancang oleh pimpinan Pondok Pesantren Sabiilunnaja beserta seluruh dewan kepengurusan pondok Pesantren Sabiilunnaja.

\section{LANDASAN TEORITIS}

Teori yang digunakan dalam penelitian ini adalah teori peran yang ada didalam kamus ilmiah. Kata peran diartikan dengan pemeran, pelaku atau pemain. Sedangkan peranan diartikan sebagai fungsi, kedudukan atau bagian kedudukan (Partanto, 1994: 585).

Peran atau role adalah suatu kedudukan yang dinamis. Jika seseorang sudah melakukan hak dan kewajibannya sesuai dengan kedudukannya, maka ia dikatakan peran (Soekanto, 2010: 212). Peran juga lain hal nya dengan posisi. Seperti yang diungkapkan oleh salah satu pengarang buku berikut ini:

Peran lebih menonjol ke fungsi, penyesuaian diri, dan sebagai suatu proses.

Sedangkan posisi adalah seseorang yang ada di dalam masyarakat (sosial position) yang merupakan unsur statis individu pada organisasi masyarakat, (Soejorno Soekanto, 2010: 212).

David Krech dan R. Cruhfield, mengemukakan fungsi seorang pemimpin yang dipegang, yaitu (1) Pelaksanaan, yang berarti melakukan suatu keputusan kelompok. (2) Perencanaan, yaitu pemimpin yang membuat rencana, pelaksanaan tetap diserahkan kepada anggota. (3) Pembuat kebijakan, maksudnya pemimpin membuat kebijakan tertentu saja yang digariskan untuk diikuti bawahan. (4) Sebagai ahli, adalah beliau yang bertindak sebagai seseorang yang mempunyai 
keahlian dalam menghadapi suatu organisasi. (5) Pengawas, yaitu orang yang selalu mengawasi setiap jalannya interaksi antar bawahan dan atasan, jika terjadinya kesenjangan. (6) Pemberi reward dan punishment, artinya pemimpin memberi reward jika ada anggota yang melakukan kebaikan lebih dan sebaliknya jika ada karyawan atau bawahan yang melakukan kesalahan, maka punishment berlaku.

Dalam buku beberapa Pandangan Umum tentang pengambilan keputusan (decisions making), Prajudi Atmosudirdjo membahas pelajaran tentang kepemimpinan, dan dalam bukunya tersebut ada berbagai bentuk yang memberikan devinisi tentang apa yang dimaksud kepemimpinan itu. Diantaranya,

Pertama, Kepemimpinan bisa dilihat sebagai penyebab awal daripada kegiatan, proses atau kejadian untuk mengubah pandangan orang lain ke kelompok yang lainnya baik dalam hubungan organisasi maupun hubungan informal.

Kedua, Kepemimpinan bisa diartikan sebagai kepribadian (personality) seseorang untuk diikuti setiap langkah geraknya, atau yang memberikan pancaran pengaruh tertentu, supaya bawahan atau orang disekitarnya mau melakukan apa yang ia lakukan atau menjadi contoh yang baik bagi bawahannya.

Ketiga, Kepemimpian yaitu suatu seni (art), kesanggupan (ability), atau teknik (technique) untuk membuat orang disekitarnya mengikuti dan menaati segala yang ia kehendakinya serta bersemangat untuk melakukannya bahkan sanggup untuk berkorban.

Pengelolaan adalah bentuk terjemahan dari kata "management," dikarenakan banyaknya suku kata yang diambil ke dalam bahasa Indonesia, istilah inggris pun beredar di Indonesia menjadi manajemen. Manajemen secara etimologi berasal dari dasar kata to manage yang artinya "mengatur, pengaturan dilakukan melalui proses dan diatur berdasarkan urutan dan fungsi-fungsi manajemen". (Hasibuan, 2006: 2). Sedangkan secara terminologis terdapat banyak pengertian yang ditemukan oleh para ahli, diantaranya adalah sebagai berikut:

Pertama, Manajemen merupakan penggunaan seluruh sumber-sumber yang ada secara tepat dalam mencapai tujuan yang sudah ditetapkan melalui proses perencanaan, pengorganisasian serta pengaturan terhadap para anggota organisasi.

Kedua, Manajemen menurut G. R Terry adalah sebuah proses yang khas yang salahsatunya tindakan-tindakan perencanaan, pengorganisasian, penggerakan dan pengawasan yang dilaksanakan untuk menentukan serta meraih suatu sasaran yang sudah ditetapkan melalui pemanfaatan sumber daya manusia dan sumber-sumber lainnya.

Ketiga, Dalam bahasa Arab, kata manajemen diartikan sebagai an-nizam atau at-tanzim yang mempunyai makna suatu wadah untuk menaruh segala sesuatu dan wadah segala sesuatu pada wadahnya, (Ilaihi, 2006: 9). 
Keempat, Robert Kritner mengartikan manajemen sebagai suatu proses melalui kerja orang lain untuk meraih tujuan organisasi didalam lingkung yang berbeda. Sumber daya manusia menjadi pusat penggunaan proses yang efektif dan efisien.

Kelima, manajemen adalah sebagai ilmu dan seni mengatur proses pemanfaatan sumber daya manusia dan sumber-sumber lainnya secara efektif dan efisien untuk mencapai tujuan yang ditentukan. (Hasibuan, 2006: 2).

Bedasarkan definisi manajemen di atas secara gamblangnya urutan dalam melakukan manajemen yaitu melakukan perencanaan, pengorganisasian, pelaksanaan, dan pengawasan.

Mastuhu berpendapat bahwasannya pondok pesantren merupakan satu lembaga pendidikan tradisional Islam guna mempelajari, mencermati, mendalami, menghayati, serta mengamalkan ajaran Islam dengan menekankan pentingnya moral keagamaan sebagai pedoman akhlakul karimah dalam kehidupan sehari-hari dalam ajaran kiai dan menjadikan kitab kuning sebagai sumber primernya.

Bentuk kepemimpinan seorang kiai dipondok pesantren tidaklah sama, tergantung bagaimana keadaan geografis, lingkungan serta karakter kiai tersebut. Dari berbagai uraian hasil suatu penelitian ada banyak pola kepemimpinan Kiai di pondok pesantren yaitu:

Pertama, kepemimpinan religio-paternalistik yaitu, bentuk interaksi kiai dengan santri didasari atas nilai keagamaan yang mencontok pola kepemimpinan baginda rosul Nabi Muhammad SAW.

Kedua, kepemimpinan paternalistic-free rein leadership, yaitu, pemipin yang pasif. Keadaan seorang ayah yang memberikan luang kepada anak-anaknya untuk berkreasi, akan tetapi bisa otoriter, yaitu memutuskan anaknya dalam melakukan suatu pekerjaan yang baik dan kurang baiknya.

Ketiga, Kepemimpinan legal formal, yaitu suatu mekanisme kerja kepemimpinan ini memfungsikan kelembagaan, pada uraian ini semua unsur memiliki peran sesuai dengan bidangnya, kemudian secara keseluruhan bekerja mensupport utuhnya kelembagaan.

Keempat, Kemimpinan bercorak alami, yaitu pola kepemimpinan yang menutup ruang untuk semua pemikiran yang bersangkutan terhadap kebijakan pesantren, hal tersebut karena menimbulkan wewenang secara mutlak. Jika ada usulan yang bertentangan, maka direspon negatif oleh kiai tersebut.

\section{HASIL DAN PEMBAHASAN}

Penelitian ini dilakukan di Pondok Pesantren Sabiilunnaja. Pondok Pesantren Sabiilunnaja merupakan bagian dari lembaga pendidikan yang ikut berperan serta 
untuk mencerdaskan umat manusia dalam menjalankan tugasnya sebagai khalifah di muka bumi ini.

Berdirinya Pondok Pesantren Sabiilunnaja pada tahun 1998 di atas tanah Waqaf dari bapak Jend. Jaja dengan tipologi salafiyah murni. Pondok Pesantren Sabiilunnaja dipimpin oleh Drs. KH. Agus Yudhi Mubaarak, S.Ag.,M.M.Pd, seorang Kyai Muda yang merupakan alumni dari Pondok Pesantren Tebuireng Jombang, selain itu Beliau juga mencari ilmu di Pondok Pesantren Darul Ulum Jombang, Pesantren Kewagean Pare Kediri, Pesantren Fauzan Cililin dan menamatkan Pendidikan formal S2 di STIMMA IMMI JAKARTA jurusan Manajemen adapun S1 diselesaikan di Universitas Hasyim Asy'ari Tebuireng Jombang.

Untuk mengembangkan kelembagaan Kemudian Pondok Pesantren Sabiilunnaja membentuk Yayasan sendiri dan telah mendapat legalisasiPesantren dari Depag dengan No. Statistik: 51.3.32.06.34.026 tahun 2005. Adapun unit Pendidikan yang diselenggarakan di Pondok Pesantren Sabiilunnaja diantaranya adalah: 1) SMA An-Naja Boarding School berdiritahun 2015. 2) SMP An-Naja Boarding School berdiri tahun 2013, 3) RA Sabiilunnajaberdiritahun 2005. 4) KoberAlhusnaberdiritahun 2007. 5) MDT Sabiilunnaja. Selain itu di Pondok Pesantren Sabiilunnaja juga menyelenggarakan Majlis Ta'lim mingguan setiap hari rabu untuk ibu-ibu, malam rabu untuk para laki-laki dan pengajian rutin alumni 2 minggu sekali setiap hari ahad.

Hasil penelitian ini menemukan sebuah strategi pimpinan dalam mengelola pondok pesantren, program pimpinan serta implementasi program tersebut. Strategi K. H. Agus Yudhi Mubaarak dalam Pengelolaan Pesantren dalam ajaran Islam diharuskan umatnya melakukan segala sesuatu secara organisir dan tertata dengan rapi. Demikian pula K. H. Agus Yudhi Mubaarak selaku pimpinan mengelola pondok Pesantren Sabiilunnaja yang dengan Lokasi Pesantren yang strategis berada di tengah-tengah kota berdampingan dengan Kantor KUA dan Masjid Besar Cipeundeuy, serta di sekitarnya bertetangga dengan Kantor UPT Pendidikan Cipeundeuy, KORAMIL Cipeundeuy, Kantor Kecamatan Cipeundeuy, Kantor POLSEK Cipeundeuy,serta sangat dekat dari Pasar tradisional Cipeundeuy dan terminal Cipeundeuy- membuat lokasi mudah dikunjungi dari arah manapun. dengan melakukan sebuah stategi guna tercapainya tujuan yang ditetapkan dalam bentuk visi misi pondok pesantren.

Dalam kepemimpinan nya K. H. Agus Yudhi Mubaarak, ada tiga strategi yang rumuskan, diantaranya adalah sebagai berikut:

Pertama, mengenalkan sifat rububiyah. Makna dari strategi rububiyah ini yaitu mengenalkan kepada santrinya bahwa hidup, mati, celaka, bahagia datang hanya dari Allah. Maka ketika seseorang meyakini bahwa Allah lah yang maha segalanya, ia tidak akan meminta apapun selain dari-Nya. Ia tidak akan mendzalimi 
dan menyekutkannya. Sama halnya dengan santri, ketika para santri sudah mengenal Allah, maka ia akan takut dalam melakukan segala sesuatu baik ketika sendiri maupun dalam keadaan banyak orang. Dan ia akan merasa jika saya mendekati Allah maka Allah akan terasa dekat. Ketika beliau menerapkan sifat rububiyah kepada santri ini, maka pimpinan pun memberi contoh kepada santri dengan meyakinkan bahwa Allah lah yang mengatur rizki setiap hambanya. Dalam hal administrasipun, jika ada anak yang kurang mampu, maka ada pembiayaan khusus bagi anak yang kurang mampu. Dengan demikian pimpinan memberikan kualitas yang terbaik bagi para santrinya. Yakni dengan memberikan harga yang terjangkau atau bisa disebut dengan murah tetapi menghasilkan santri/anak didik yang berprestasi. Tidak hanya unggul dibidang intelektualnya saja akan tetapi dibidang spiritualnya pun juga.

Strategi yang kedua adalah pimpinan dalam mengelola pondok Pesantren Sabiilunnaja adalah pembiasaan menyeimbangkan hubungan horizontal dan hubungan vertikal. Yakni tujuan strategi ini agar seimbang antara hubungan santri dengan sang pencipta dan hubugan santri dengan pimpinan, baik dengan asatidz ataupun dengan santri yang lainnya. Tidak semua orang yang pertama masuk pondok pesantren adalah orang yang pandai dalam beribadah. Karna pada dasarnya orang tua memasukan anaknya ke pesantren yaitu menginginkan seorang buah hati nya bisa menjadi anak yang mempunyai perangai yang baik dan terpuji. Strategi ini dirancang karena beberapa santri yang masuk pesantren dari tempat tinggal asalnya memiliki perangai yang kurang baik, maka dengan itu pimpinan dalam mengatasi kenakalannya diadakannya pembiasaan-pembiasaan yang mengalihkan kenakalannya kepada pembiasaan baik. Dengan adanya visi dan misi pesantren serta program-program yang ada dipesantren Sabiilunnaja, maka pimpinan dan seluruh pihak kepesantrenan akan senantiasa berusaha semaksimal mungkin mewujudkan generasi yang mampu menjadi seorang pemimpin yang berwawasan luas dan berperilakunya mencontoh dari Al-quran dan Al-Hadits, senantiasa berusaha mencetak generasi yang soleh dan tidak tertinggal dalam menghadapi zaman yang milenial ini. Dengan demikian pimpinan mengawali para santri dengan pembahasan fardu ain. Terlebih pembahasan yang lain seperti tafsir, hadis, dan lain-lain. Akan tetapi ada yang yag lebih utama yaitu, penerapan fardu ain. Seperti Bab sholat, wudhu dan adus. Apalagi seorang wanita yang biasa mengeluarkan darah setiap bulannya atau disebut dengan darah haid. Belum lagi setelah menikah akan ada macam-macam darah yang keluar dari vagina perempuan. Dan ini sangatlah urgent bagi kaum perempuan. Pembiasaan menyeimbangkan hubungan horizontal dan hubungan vertikal ini dilakukan dalam menjalanakan salah satu program dari pesantren ini, yaitu pembiasaan sholat tahajud, sholat dhuha, membaca Al-quran, sholat berjamaah, dan shodaqoh.

Ketiga, strategi pimpinan dalam mengelola pondok Pesantren Sabiilunnaja adalah meningkatkan intelektualisme dan spiritualisme. Mencerdaskan anak 
bangsa dibidang intelektual maupun spiritual adalah kewajiban kita bersama. Baik orangtua, masyarakat maupun pemerintahan dalam rangka membangun bangsa ke arah kemajuan yang seimbang menuju mardhotillah yaitu kesuksesan lahir dan batin. Menjawab hal itu pendidikan merupakan jalan terbaik menuju cita-cita dan harapan kita bersama.

Maka dengan demikian pimpinan pondok pesantren Sabiilunnaja bersusah payah dengan kekuatan yang menggebu untuk mewujudkan cita-cita tersebut. Untuk meningkatkan intelektualisme dan spiritualisme, Berikut penyelenggaraan berbagai program pendidikan, baik formal maupun nonpormal, diantaranya: (1) Kelompok Bermain (Kober) Al-husna. lembaga ini diselenggarakan bagi anakanak pra TK (3-4 tahun). dengan waktu belajar 3 kali pertemuan dalam seminggu. (2) Raudhotul Athfal (RA), merupakan lembaga formal pertama yang diselenggarakan di Pondok Pesantren Sabiilunnaja dengan program pendidikan diperuntukkan bagi para anak pra SD (4-6 tahun). didirikan sejak tahun 2005 dengan bertujuan untuk membimbing anak dalam segala hal yang bermaterikan bimbingan-bimbingan ilmu dan akhlak (adab-adab) yang dipadukan antara ilmu agama dan ilmu umum sebelum anak memulai belajar di Sekolah Dasar. saat ini RA Sabiilunnaja telah terakreditasi "B", dengan jumlah Peserta Didik terbanyak di wilayah Kecamatan Cipeundeuy dan ketiga terbanyak di Kabupaten Bandung Barat. (3) Madrasah Diniyyah Takmiliyah, lembaga non formal yang diselenggarakan untuk para anak-anak se-usia sekolah dasar dan sekolah menengah pertama. bagi mereka yang tidak tinggal di Pondok. adapun jam belajarnya siang sampai sore. (4) SMP An-naja Boarding School. lembaga yang didirikan sejak tahun 2013. program yang di utamakan adalah bimbingan fardu 'ain, bimbingan tajwid dan tahsin, Kajian Kitab Kuning, bimbingan khat serta bimbingan bahasa arab \& bahasa Inggris, sekolah ini menyelenggarakan pendidikan terpadu antara ilmu agama dan ilmu umum yang terintegrasi dalam pembelajaran 24 jam. (5) SMA An-naja Boarding School. merupakan sekolah lanjutan dari SMP An-naja Boarding School yang didirikan sejak tahun 2014, SMA ini merupakan lembaga yang tidak terpisahkan dari keberadaan SMP An-naja Boarding School sebagai satu paket program. program-program yang diberikan merupakan program lanjutan dari program SMP An-naja Boarding School, materi praktek lebih ditekankan pada jenjang ini. (6) Majlis ta'lim. setiap hari rabu untuk kaum hawa serta rabu malam bagi kaum adam. (7) Bimbingan Manasik Haji \& Umroh.

Pondok Pesantren Saabiilunnaja ini salah satu pondok pesantren yang termasuk ke dalam pesantren Boarding School jadi seluruh santri yang ada dipesantren semuanya mengikuti sekolah formal yaitu jenjang SMP An-Naja dan SMA An-Naja. Seluruh kegiatan baik pesantren maupun sekolah sudah dikemas dengan menggunakan kurikulum yayasan. 
Dengan meningkatkan intelektualime dan spiritualisme beliua membuat program-program yang telah dirancang oleh pimpinan dan seluruh jajaran dewan guru pondok Pesantren Sabiilunnaja. Dengan adanya program tersebut menjadi wadah maju dan berkembangnya santri baik intelekrualnya maupun spiritulanya.

Hasil penelitian ini beracuan pada teori peranan seorang pemimpin yang dikemukakan oleh kartono bahwa peran seorang pemimpin adalah sebagai pelaksana, perencana, sebagai seorang ahli, sebagai pengawas, bertindak sebagai pembri gambaran atau pujian atau hukuman, pemegang janggung jawab dan bertindak sebagai seornag ayah. (Kartono, 2018: 15)

\section{Program K. H. Agus Yudhi Mubaarak dalam pengelolaan pesantren}

Keberhasilan seorang pemimpin dilihat dari program kerja serta implementasinya. K.H. Agus Yudhi Mubaarak membagi program nya menjadi tiga, yaitu program waktu panjang, waktu pendek, dan waktu mengengah. Pada program waktu panjang di Pondok Pesantren Sabiilunnaja ialah kelas takhosus tahfidz qur'an. Kelas Takhosus tahfidz qur'an merupakan program jangka panjang untuk santri yang tinggal diasrama (mondok) baik tingkat SMP maupun SMA. Kegiatan ini dilakukan dengan tujuan: (1) santri hafal al-qur'an sekurang-kurangnya 1 juz pertahunnya; (2) santri mampu membaca al-qur'an secara fasih; (3) lebih mencintai Al-Qur'an dimanapun santri berada; (4) merasakan nikmatnya belajar Al-qur'an; (5) memiliki adab dalam membaca dan mendengarkan Al-qur'an.

Kemudian, pada program jangka pendek, terbagi menjadi program yang bersifat harian dan mingguan. Adapun pada program harian, mencakup: (1) Bimbingan kitab kuning. Bimbingan kitab kuning merupakan kegiatan sehari-hari santri dalam mendalami ilmu kepesantrenan. Tujuan dari bimbingan ini, melatih santri agar mampu menguasai serta memahami ilmu-ilmu keseharian yang sering dilaksanakan. Seperti halnya ilmu sholat, ilmu wudhu dan ilmu-ilmu yang lainnya yang mencakup kedalam ibadah, muamalah, perniagaan dan pernikahan. (2) KBM (Kegiatan Belajar Mengajar) Kegiatan ini menjadi kegiatan pokok bagi seluruh santri dalam mendalami ilmu keduniawian. Tujuan dari kegiatan belajar mengajar ini yaitu agar santri tidak hanya mengetahui ilmu agama saja akan tetapi ilmu yang dipakai dalam dunia kerja. Sama pentingnya baik ilmu dunia maupun akhirat kita wajib mencarinya dan mendalami. (3) Bimbingan bahasa arab dan inggris. Bimbingan bahasa arab dan inggris ini merupakan kegiatan santri khusus santri yang menetap diasrama. Kegiatan ini pula merupakan kegiatan sehari-hari santri dalam hal menguasai bahasa asing. Tujuan utamanya agar santri mampu menyelaraskan pada era sekarang ini. Karena tidak bisa dipungkiri lagi dan semakin maju perkembangan ilmu pengetahuan dan teknologi. Seperti yang kita tahu, bahwasannya bahsa inggris yang mayoritas semua sudut pandangan dalam komunikasi antar bangsa. Tidak disangkal jika bahasa asing perlu sekali dibutuhkan pada era ini, terlebih bahasa inggris. (4) Sholat tahajud dan dhuha bersama yang merupakan kegiatan sehari-hari santri dalam melaksanakan ibadah sunnah ini. 
Kegiatan ini bertujuan unruk menerapkan pembiasaan baik bagi santri agar tahu akan wajibnya sebagai hamba tuhan dan mengenalkan keseimbangan kecerdasan intelektual dan kecerdasan spiritual. Kegiatan ini pun sangat menjungjung tinggi nilai yang positif, yakni dengan adanya kegiatan wajib sholat tahajud dan dhuha mampu menbiasakan santri sholat sunnah menjadi kebutuhannya sehari-hari baik dipesantren maupun dirumah. Serta menjaga hubungan baik dengan Allah dan hubungan baik dengan kehidupan atau lingkungan sosialnya.

Adapun kegiatan mingguan adalah: (1) Khatam Al-quran. Khatam al-quran merupakan kegiatan mingguan santri Pondok Pesantren Sabiilunnaja yang bertujuan pembiasaan baik yang wajib diaplikasikan setiap hari dalam kemajuan spiritual santri. Khatam Al-Qur'an dilakukan oleh seluru santri baik perempuan maupun laki-laki yang dipandu langsung oleh pimpinan. (2) Kegiatan ekstrakulikuler. Kegiatan ekstrakulikuler adalah kegiatan nonformal yang dilakukan oleh santri baik perempuan maupun laki-laki disekolah. Yang bertujuan agar siswa dapat menunjukan kepribadiannya, menumbuhkan bakatnya, serta kemampuannya diperbagai aspek di luar aspek akademik. Seperti qasidah, pramuka dan yang lainnya.

Dan yang selanjutnya adalah Program jangka pertengahan, yang mencakup: (1) Kunjungan edukatif. Kunjungan edukatif yaitu kegiatan kunjungan atau rihlah kesuatu tempat yang bertujuan untuk siswa selalu mencintai alam semesta dengan melihat, merawat setiap keagungan Allah dalam menciptakan alam. (2) OMOB (One Month One Book). OMOB ini merupakan kegiatan gerakan literasi yang bertujuan untuk melatih siswa membaca buku perbulannya.

Sesuai dengan teori bahwasannya Program di dalam Kamus Besar Bahasa Indonesia (KBBI) diartikan sebagai usulan atas asar-asas dan kerja keras yang akan dilaksanakan (Jones dalam Rohman, 2009: 101-102).

\section{Implementasi program K. H. Agus Yudhi Mubaarak dalam pengelolaan pesantren.}

Keberhasilan pimpinan terdapat dari bagaimana implementasi dalam program kerjanya. Ini beberapa impelentasi dari program yang K. H. Agus Yudhi Mubaarak rancang. Yaitu:

Kelas takhosus tahfidz qur'an merupakan program yang diadakan oleh pimpinan dengan menggunakan metode pembiasaan dalam penerapannya, adapun dalam prosesnya meliputi: Pertama, Pembimbing kelas takhosus tahfidz qur'an di yayasan Pondok Pesantren Sabiilunnaja yaitu: Ibu Abilla Zainatu Millah, M. Pd. Kedua, Kegiatan kelas takhosus tahfidz qur'an merupakan kegiatan wajib yang dilaksanakan oleh seluruh santri baik perempuan maupun laki-laki baik tingkatan SMP maupun tingkatan SMA. Ketiga, Waktu pelaksanaan. Pelaksanaan kelas takhosus tahfidz qur'an dilaksanakan pada pukul 07.30 s.d pukul 08.00. Setiap santri memiliki dewan pembimbingnya masing-masing. 
Kemudian implementasi dari bimbingan kitab kuning. Salah satu kewajiban santri tinggal dipesantren adalah mengaji. Dipondok Pesantren Sabiilunnaja ditekankan pada pembahasan fardu aen baik secara teoritis maupun secara praktis. Proses pelaksanaan kitab kuning adalah sebagai berikut: Pertama, Pembimbing kitab kuning dipondok Pesantren Sabiilunnaja adalah Bapak Mansur, S. Pd. Pembimbing kitab kuning melibatkan beberapa dewan guru lainnya. Kedua, Terbimbing dalam kegiatan bimbingan kitab kuning dipondok Pesantren adalah seluruh santri baik perempuan maupun laki-laki. Ketiga, metode yang digunakan oleh dewan guru pondok Pesantren Sabiilunnaja berupa metode ceramah, mentoring, dan diskusi. Ketiga metode ini dilaksanakan tidak secara berbarengan, artinya ketiga metode ini dilaksanakan sesuai jadwal yang telah ditentukan.

Metode ceramah dilakukan dalam bimbingan kitab kuning ini karena dalam waktu yang singkat materi bisa tersampaikan dengan singkat dan jelas. Metode ceramah ini juga melatih santri supaya pandai dalam hal mendengar. Karna tidak banyak orang yang pandai berbicara pandai juga mendengar. Adapun metode selanjutnya adalahh metode mentoring. Metode mentoring sering juga disebut dengan sorogan (bahasa pesantren). Yakni santri belajar kembali atau mengulas pelajaran yang tertinggal kepada dewan guru. Metode ini disampaiakan secara face to face. Adapun metode berikutnya yaitu metode diskusi. Metode diskusi yaitu metode yang dilaksanakan secara kelompok. Yakni metode yang dilaksanakan seluruh santri guna melatih memecahkan masalah.

Keempat materi yang disampaikan pada bimbingan kitab kuning adalah materi yang berkaitan dengan materi fardu ain yang bertujuan utama ialah supaya santri tidak hanya cerdas dalam hal intelektual saja akan tetapi cerdas dalam hal spiritual juga. Materi kitab kuning diantaranya meliputi materi-materi tentang ilmu nahwu, shorof, fiqh, ushul fiqh, tauhid, tafsir, dan hadist.

Kelima, Media. Dalam pelaksanaan program bimbingan kitab kuning, media yang menunjang dalam pemberian materi adalah bersifat material atau disebut dengan washilah madiyah berupa ruangan pengajian, terkadang juga menggunakan alat tulis seperti spidol, bor dan yang lainnya untuk memudahkan dewan guru dalam menerangkan uraian terutama materi yang berupa ilmu nahwu dan shorof.

Keenam, Program bimbingan kitab kuning dilaksanakan setiap hari pada waktu pagi-pagi pukul $05.30 \mathrm{~s} / \mathrm{d}$ pukul 06.00 dan diwaktu malah hari pada jam $19.00 \mathrm{~s} / \mathrm{d}$ jam 21.00 .

Kegiatan belajar mengajar merupakan kegiatan formal. Disamping santri mengaji kitab kuning, santri pun belajar disekolah. Adapun pelaksanaannya dianataranya sebagai berikut: 1) Seluruh dewan guru terlibat dalam kegiatan belajar mengajar sesuai dengan keilmuan yang beliau kuasai. 2) Seluruh santri yang sekolah disini menurut kelas dan jenjangnya. 3)Kegiatan belajar mengajar ini dilaksanakan setiap hari baik yang sekolah jenjang mengenah pertama (SMP) maupun jenjang menengah atas (SMA). Dilakukannya kegiatan ini pada jam 08.00- 
10.20. dengan jadwal yang sudah ditetapkan oleh seluruh guru dalam musyawarah awal semester. Kemudian istirahat pukul 10.25 sampai 10.50. kemudian dilanjut pukul 10.50 sampai 12.10 . setelah itu istirahat kembali dan dilanjut pada pukul 3.45-16.00.

Bimbingan bahasa arab dan inggris. Program ini merupakan program yang bertujuan untuk santri tidak asing dalam menggunakan bahasa asimg imi. Orang yang terlibat dalam program bimbingan bahasa Arab dan Inggris yaitu: (1) Pembimbing bahasa Arab dan Inggris dipisah. Untuk bahasa Arab yaitu Bapak asep Yusuf Sopian Rijal, S. Pd. I. Dan untuk pembimbing bahasa inggris adalah Ibu Rina Hasanah, S. Pd. I. (2) Terbimbing dalam kegiatan program ke-bahasaan ini adalah seluruh santri pondok Pesantren Sabiilunnaja baik perempuan maupun laki-laki. (3) Metode dalam program kebahasaan ini adalah menggunakan metode hafalan. Yakni seluruh santri atau siswa baik perempuan maupun laki-laki diberikan mufradat setiap kelasnya kemudian dihaflakan secara berbarengan dipandu oleh wali kamarnya masing-masing. (4) Waktu pelaksanaan program ini yaitu setiap hari. Akan tetapi sesuai jadwal yang sudah ditetapkan. Yaitu satu minggu menggunakan bahasa Arab satu minggu menggunakan bahasa Inggris. Dan proses pelaksanaan ini belum begitu terlendingkan santri masih terbiasa menggunakan bahasa sehari-harinya.

Program pelaksanaan sholat tahajud dan dhuha bersama merupakan salah satu strategi pimpinan dalam menerapakn pembiasaan baik kepada seluruh santri pondok Pesantren Sabiilunnaja. Waktu pelaksanaan sholat tahajud ialah satu jam sebelum waktu subuh tiba yakni sekitar pukul 03.30 samapi pukul 04.30. kemudian waktu pelaksanaan dhuha yaitu pada pukul $07.00 \mathrm{~s} / \mathrm{d}$ pukul 07.30. Pelaksanaan sholat sunnah tahajud dan dhuha ini dilaksanakan oleh seluruh santri pondok Pesantren Sabiilunnaja baik perempuan maupun laki-laki. Hanya saja tempatnya yang berbeda. Perempuan di aula pondok Pesantren Sabiilunanaja yang dibimbing langsung oleh istri pimpinan pondok pesantren yaitu Ibu $\mathrm{Hj}$. Rina Ismatillah Ridwan, M. Pd. Dan untuk laki-laki di Masjid yang dibimbing langsung oleh pimpina Pondok Pesantren Sabiilunnaja yaitu K. H. Agus Yudhi Mubaarak, S. Pd., M. Ag.

Implementasi dari kegiatan ekstrakurikuler ini dilaksanakan dalam kegiatan formal pondok Pesantren Sabiilunnaja yaitu di tingkat SMP An-Naja Boarding School dan SMA An-Naja Boarding School. Dilaksanakan oleh seluruh santri pondok Pesantren Sabiilunnaja. Waktu pelaksanaannya yaitu pada hari minggu dan pada hari jum'at.

Adapun kegiatan ekstrakurikuler di tingkatan SMP An-Naja Boarding terdiri dari: (1) Pramuka; (2) Hadrah; (3) Beladiri; (4) Futsal; (5) Qasidah; (6) Tataboga, dan (7) Arsitektur.Kegiatan ini dibagi menjadi dua kategori, yaitu kegiatan wajib dan pilihan. Kegiatan ekstrakurikuler yang wajib, yakni seluruh 
santri wajib mengikuti kegiatan ini adalah pramuka. Sedangkan kegiatan pilihan adalah hadroh, beladiri, futsal, qasidah, tataboga dan arsitektur. Kegiatan pilihan ini sesuai bakat dan minta siswa. Kemudian kegiatan ekstrakulikuler pada tingkatan SMA diantaranya: (1) Pramuka; (2) PIK-R; (3) Menjahit; (4) Budidaya tanaman; (5) Pengolahan kerajinan; (6) Perisai diri; (7) Hadrah; dan (8) Karya ilmiah.

Program kunjungan edukatif dilaksanakan pada ahkir semester genap baik tingkatan SMP maupun tingkatan SMA. Kegiatan ini dilaksanakan oleh seluruh santri beserta wali kelas nya masing-masing. Kegiatan ini diadakan secara musyawarah baik tempat maupun waktunya. Biasanya terlebih dahulu diadakannya kepanitiaan. Guna terorganisirnya program yang akan dilendingkan.

Pada program khatam Al-Qur'an Mingguan dilaksanakan setiap satu seminggu sekali pada hari Minggu secara berjama'ah. Kegiatan ini juga kegiatan wajib bagi seluruh santri pondok pesantren Sabiilunnaja baik perempuan maupun laki-laki. Dan dibimbing oleh Ibu Hj. Rina. Proses pelaksaan hatam Al-qur'an ialah dengan pembimbing membagikan satu juz Al-Qur'an per santrinya. Dibantu oleh santri kemudian dibagi perkelompok dalam membagikan perjuznya. Setelah itu khatam qur'an dibuka langsung oleh Ibu $\mathrm{Hj}$. Rina dan serentak alunan ayat-ayat Al-qur'an dilantunkan oleh ratusan santri sampai selesainya dan ditutup kembali oleh Ibu Hj. Rina.

Implementasi dari OMOB (One Month One Book) ini dilaksanakan pada satu bulan sekali minimal satu buku. Pelaksanaannya dianjurkan kepada seluruh siswa. Adapun siswa pilihan yaitu siswa yang akan ikut perlombaan, program ini dilaksanakan satu bulan minimal 3 buku. Pelaksanaan ini dibimbing oleh Asep M. Ramdani, S. Pd.

J. Salusu (1996: 409) berpendapat baahwa implementasi adalah ialah aktivitas yang dilakukan secara bertahap pada satu keputusan. Dan juga bisa disebut sebagai operasionalisasi dari aktivitas-aktifitas untuk tercapainya suatu sasaran tertentu. Dalam organisasi serangkaian aktivitas dibutuhkan untuk mencapai satu sasaran. Oleh sebab itu, implementasi dapat juga disebut sebagai operasionalisasi dari berbagai macam aktivitas (Yunus, 2014: 112).

\section{PENUTUP}

Berdasarkan hasil penelitian tentang kepemimpinan efektif di Pondok Pesantren Sabiilunnaja Kecamatan Cipeundeuy Kabupaten Bandung Barat peneliti menyimpulkan sebagai berikut:

Pertama, strategi yang K. H. Agus Yudhi Mubaarak lakukan dalam mengelola pondok pesantren dari pertama dibangun hingga detik ini adalah mengacu pada tiga strategi. (1) strategi yang beliau rancang adalah pengenalan sifat 
rububiyah yakni mengesakan tuhan. Sebelum berlanjut ke-tahap yang lain sifat rububiyah ini yang selalu ia terapkan kepada seluruh orang yang ada disekitarnya, baik keluarga, santri, dewan guru sampai masyarakat tiada lain tiada bukan strategi ini memancing khalayak agar yang pertama dikenal ialah Allah, melakukan aktivitas apapun melibatkan Allah, urusan sebesar apapun melibatkan Allah, dan supaya selalu berhusnnudzon kepada Allah karena orang yang berhusnudzon kepada Allah niscaya hidupnya akan tenang. (2) ialah pembiasaan baik. Khususnya pembiasaan dalam mensinergikan hubungan horizontal dan hubungan vertikal. Pembiasaan ini beliau berikan kepada santri dan kepada seluruh pihak kepesantrenan agar selalu seimbang dalam komunikasi dengan Tuhan-Nya (hubungan horizontal) dan komunikasi dengan makhluknya (hubungan vertikal). Dan (3) strategi yang beliau lakukan adalah meningkatkan spiritualisme dan intelektualimse. Disamping tujuan utama beliau membangun sekolah untuk kemaslahatan santri, disini juga beliau membangun sekolah guna meningkatkan spiritualisme dan intelektualismenya supaya antara sekolah dan pesantren sama rata. Jadi tidak berat sebelah antara duniawi dan ukhrowi dua duanya tetap diprioritaskan.

Kedua, Program K. H. Agus Yudhi Mubaarak dalam pengelolaan pesantren ini tidak serta merta dibuat oleh sendiri, akan tetapi ada campur tangannya dengan para asatidz diwilayah pesantren melalui musyawarah. Program dipondok Pesatren Sabiilunnaja ini terbagi dalam tiga kategori, (1) program waktu pendek, (2) program waktu menengah dan (3) program waktu panjang.

Program waktu pendek terbagi menjadi dua, yaitu program harian dan program mingguan. Program harian ini meliputi: bimbingan kitab kuning, KBM (kegiatan belajar mengajar), bimbingan bahasa asing (Bahasa Arab dan Bahasa Inggris), dan Sholat Tahajud dan Dhuha bersama. Adapun program jangka pendek yang bersifat mingguan adalah khatam qur'an dan kegiatan ekstrakulikuler. Adapun program jangka menengah, yaitu program yang dilaksanakan setiap satu bulan atau satu semester sekali. Kegiatannya diantaranya adalah kunjungan edukatif dan OMOB (One Month One Book). Pada program jangka panjang ini dilakukan setiap tahun sekali. Program ini dinamakan kelas takhosus tahfidz qur'an.

Ketiga, Implementasi dari program-program K. H. Agus Yudhi Mubaraak dalam pengelolaan pesantren di atas berjalan sesuai dengan yang diharapkan, meskipun ada program yang belum maksimal. Dalam mengimplementasikan, orang yang terlibat dalam seluruh program ini adalah seluruh santri dan dewan guru. Pelaksanaan program yang ada di Pesantren Sabiilunnaja dilaksanakan sesuai jadwal yang sudah dibuat oleh pimpinan dan dewan guru. 


\section{DAFTAR PUSTAKA}

Daryanto. (1997). Kamus Umum Bahasa Indonesia. Jakarta : Penerbit Rosda karya. Karjadi, 1989. Kepemimpinan.Bogor : POLITEIA.

Kartini, K. (2008). Pemimpin dan Kepemimpinan (Apakah Kepemimpinan Abnormal itu?). Jakarta: Rajawali Pers.

Malayu S. P. H. (2006). Manajemen (Dasar, Pengertian dan Masalah), Jakarta: Bumi Aksara.

Manulang. (1990). Dasar-dasar Manajemen. Jakarta: Galia Indonesia.

Munir, M. \& Ilaihi, W. (2006). Manajemen Dakwah. Jakarta: Kencana Perdana Media Group.

Muhammad, (2015) Kepemimpinan Kiai Dalam Membentuk Etos Kerja Santri; dalam tadbir: jurnal Manajemen Dakwah: 233.

Suharsini, A. (2006). Statistik Untuk Penelitian. Bandung: ALFABETA.

Yunus. (2014). Perencanaan, Implementasi, dan Evaluasi Kebijakan. Unit Penerbitan Universitas Majalengka.

Zamakhsyari, D. (1994). Tradisi Pesantren (Studi Tentang Pandangan Hidup Kiai) Jakarta : LP3ES (Lembaga Penelitian, Pendidikan, Dan Penerangan Ekonomi Dan Sosial). 